\title{
The role of contractor in improving buildability in construction projects in Bali
}

\author{
I Putu Ari Sanjaya ${ }^{1, *}$, I Gede Putu Joni ${ }^{1}$, and Ariany Frederika ${ }^{1}$ \\ ${ }^{1}$ Department of Civil Engineering, Universitas Udayana, Denpasar, Indonesia
}

\begin{abstract}
Buildability is defined as the optimum use of construction knowledge and experience (time, cost, quality) at the planning, design, procurement, and field implementation stages so that the building can be completed effectively, efficiently and of good quality. The successful application of the buildabbility improvement program depends on the commitment of all members of the project management team to achieve success. The project management team includes the owner of the project planning and implementation. The aim of the research is to find out the important principle of buildability so that the contractor can play a bigger role in improving constructability. Data collection was carried out by questionnaires and interviews. The results of the analysis showed that the role of the contractor in improving buildability was the highest in the factor of Construction knowledge, team expertise and integration.
\end{abstract}

\section{Introduction}

Construction projects have particular characteristics because they are very different from the services of other industries. These specific traits are characterized by high business risk, full of uncertainty, quality and schedule determined by service users and always changing stages.

Competition is also unavoidable in the construction industry. Currently, construction service providers are required to be innovative in planning and implementing construction. This also affects the type of contract or approach taken in the execution of construction. At present, the contract or approach to the implementation of construction is mostly carried out with a traditional approach where the year. The characteristics of this contract or approach are very long construction phases because there are different contracts between planning and implementation contracts. The weakness is the lack of communication between the planner and the implementer so that the project owner's goal of the project is often not achieved both in terms of time, quality and cost. For this reason, buildability plays a role in improving project performance.

In 1983, Business Roundtable's Construction Industry Cost Effectiveness (CICE), for four years conducted a study on how to improve quality, efficiency, productivity and costeffective in construction projects with the result that increasing "Buildability" can save $10 \%$ to $20 \%$ of project costs. Similarly, the experience gained from the project owner revealed that the implementation of the construction schedule acceleration without increasing buildability could increase construction costs directly to an average of $25 \%$ [1].

Improved buildability will be achieved optimally if there is integration at each stage of the project. The contracting contractor has a significant role in contributing to improving buildability. But not all implementing contractors understand and understand the

\footnotetext{
*Corresponding author: iparisan71@gmail.com
} 
importance of buildability for increasing efficiency and productivity in the field, so that a lot of field engineering is generated, but not with the ability to build. As a result, the implementation costs in the field swell due to delays in implementation time due to the termination of the project activities in the field to improve the design so that it can be implemented by the contractor [2]. However, service users as integrators between the planning process and implementation must be sensitive to see problems that may occur or often occur in the conduction process. "Buildability" can be seen as an issue that needs to be studied. Seeing the closeness of the relationship there is a contractor who constructs a building that is "buildable" with service users as an integrator between the field engineering process and implementation. Besides that, "Buildability" is also a problem that has not been widely studied in Indonesia. The research objective is to analyze the principles of buildability that need to be applied by the contractor so that the project objectives can be achieved.

\section{Buildability}

Buildability is also defined as the ability to construct buildings efficiently, economically and to decide the quality level of material selection, components, and sub-installation [3]. According to Austin, USA's Construction Industry Institute (CII) "Buildability" is defined as "the optimum use of construction knowledge and experience at the planning, design, procurement, and field implementation stages so that the building can be completed effectively, efficiently and of good quality" [4]. The American Society of Civil Engineers or Awareness of implementing buildability is effective in reducing project costs and time, beginning in the mid-1970s [5]. Especially in the last five years, the application of buildability is increasing. This has resulted in a more in-depth application of buildability programs in informal places scattered in individual companies [2]. Actually the issue about buildability is not new. There have been many topics related to project management and control that lead to buildability. It's just that in the last ten years, the Construction Industry Institute (CII) has formally begun to develop generic concepts about buildability.

Principle buildability continues to grow from year to year. The principle that initially existed 7 (CIRIA) then developed to 16. In America then developed into 14 principles and by CIIA finally summarized into 12 principles. But basically, the above principles have the same description. The 12 Buildability principles are as follows: 1) Integration, 2) Construction knowledge, 3) Team skill, 4) Corporate objectives, 5) Available resource, 6) External factors, 7) Program, 8) Construction method, 9) Accessibility, 10) Specification, 11) Construction innovation, and 12. Feedback.

The principles of building buildability in the contractor can be by making a checklist whether the application of buildability has been applied or not. The principles of buildability are also used to each project life cycle as in Table 1 [6].

For the concept of effective buildability itself, it starts early, i.e., since the feasibility study reaches the post-construction stage. More savings will be obtained if the program is implemented in the initial stages of the project. However, buildability programs that are well designed must be carried out at all stages of the project to maximize overall savings.

In the implementation of construction projects, there are often problems related to the project itself. This can be caused by factors outside the project itself and the factors within the project, such as project performance. Issues that cannot be anticipated and dealt with will not lead to the achievement of project objectives so that efficiency and effectiveness in project implementation cannot be carried out. For that buildability is needed in construction projects to be able to solve the construction problems. 
Table 1. Buildability principle in project life cycle.

\begin{tabular}{|c|c|c|c|c|c|c|}
\hline \multirow[b]{2}{*}{ No } & \multirow{2}{*}{$\begin{array}{c}\text { Buildability } \\
\text { principles }\end{array}$} & \multicolumn{5}{|c|}{ Typical project life cycle } \\
\hline & & Feasibility & Concept & Design & Construction & $\begin{array}{c}\text { Post } \\
\text { construction }\end{array}$ \\
\hline 1 & Integration & 4 & 4 & 3 & 3 & 3 \\
\hline 2 & $\begin{array}{l}\text { Construction } \\
\text { knowledge }\end{array}$ & 3 & 4 & 3 & 3 & 1 \\
\hline 3 & Team skill & 2 & 1 & 1 & 1 & 1 \\
\hline 4 & $\begin{array}{l}\text { Coporate } \\
\text { objectives }\end{array}$ & 4 & 4 & 1 & 1 & 3 \\
\hline 5 & $\begin{array}{l}\text { Available } \\
\text { resource }\end{array}$ & 4 & 2 & 2 & 1 & 1 \\
\hline 6 & $\begin{array}{l}\text { External } \\
\text { factors }\end{array}$ & 3 & 2 & 3 & 1 & 1 \\
\hline 7 & Program & 3 & 4 & 4 & 4 & 1 \\
\hline 8 & $\begin{array}{l}\text { Construction } \\
\text { method }\end{array}$ & 1 & 1 & 4 & 1 & 1 \\
\hline 9 & Accessibility & 1 & 1 & 1 & 4 & 1 \\
\hline 10 & Specification & 1 & 1 & 1 & 1 & 1 \\
\hline 11 & $\begin{array}{l}\text { Construction } \\
\text { innovation }\end{array}$ & 1 & 1 & 1 & 4 & 1 \\
\hline 12 & Feedback & 1 & 1 & 1 & 1 & 4 \\
\hline
\end{tabular}

note: $1=$ not relevant, $2=$ relevant, $3=$ moderately relevant, $4=$ high relevant.

The benefits of buildability directly and indirectly [1,7]. The direct benefits are as follows: 1) construction planning becomes easier, 2) the cost of design and construction can be reduced, 3) the construction schedule can be shortened, 4) the quality of work and results can be better, 5) there are realistic responsibilities and commitments for future work, and 6) the owner's role has begun as early as possible.

The indirect benefits are as follows: 1) indirectly build teamwork with one vision to achieve project objectives, 2) each stakeholder works in mutual benefit, 3) the crossing of the distribution of scientific disciplines, 4) experience transfer, 5) the contractor will better understand the design and vice versa; designers will better understand project construction, 6) open opportunities for design and construction innovation, 7) the learning curve can be shortened, and 8) as an advantage to be able to compete in the construction business.

\section{Methodology}

Interview and questionnaire survey were conducted to address the aim of this research. First of all, interview was conducted to obtain the factors that can improve buildability. The interview involved five respondents. Interviewees were experts who are competent in 
construction project especially in buildability. They were asked their opinion regarding factors improving buildability. Subsequently, the result of interview survey were combined with iterature review for developing questionnaire. Questionnaires were distributed to 30 respondents as research sample who were competent in construction project especially in buildability. Respondents consisted of contractor staff who were directly work in the project. Respondents were asked to give a response regarding factors improving buildability that needed to be implemented by the contractors. Respondents were asked to give priority to the principles of buildability. Data analysis used was descriptive analysis using frequency analysis. After obtaining frequency values, the principle that is considered most important in buildability is obtained.

\section{Results and discussion}

After the questionnaire was given to the respondents, the results were then analyzed by descriptive analysis using frequency analysis. Each principle or factor is has frequency whereby the greatest frequency indicated the most important factor or principle and becomes the top sequence.

Table 2. Factors/principles improving buildability [3].

\begin{tabular}{|c|l|}
\hline No & \multicolumn{1}{|c|}{ Factors/principle } \\
\hline 1. & Integration \\
\hline 2. & Construction Knowledge \\
\hline 3. & Team Skill \\
\hline 4. & Coporate Objectives \\
\hline 5. & Available Resource \\
\hline 6. & External Factors \\
\hline 7. & Program \\
\hline 8. & Construction Method \\
\hline 9. & Accessibility \\
\hline 10. & Specification \\
\hline 11. & Construction Innovation \\
\hline 12. & Feedback \\
\hline
\end{tabular}

Table 2 shows factors that need to be considered in the improvement of Buildability by the contractors. These factors were given to respondents in order to obtain the frequencies of the factors.

Table 3 and 4 show the frequencies of the factors/principles of Buildability. The highest frequencies are construction knowledge and team skill which have frequencies of $100 \%$. It indicates that construction knowledge and team skill should be considered in improving Buildability. Available resource, construction method and construction innovation are positioned in second place which have frequencies of $97 \%$, and followed by integration, accessibility and specification which have frequencies of $77 \%$. The lowest 
frequency includes cooperate objectives, external factors and feedback which have frequencies of $7 \%$.

Table 3. Frequency of buildability.

\begin{tabular}{|c|l|c|}
\hline No & \multicolumn{1}{|c|}{ Factors/principles } & Frequency (\%) \\
\hline 1. & Integration & 77 \\
\hline 2. & Construction Knowledge & 100 \\
\hline 3. & Team Skill & 100 \\
\hline 4. & Coporate Objectives & 70 \\
\hline 5. & Available Resource & 97 \\
\hline 6. & External Factors & 70 \\
\hline 7. & Program & 77 \\
\hline 8. & Construction method & 97 \\
\hline 9. & Accessibility & 77 \\
\hline 10. & Specification & 77 \\
\hline 11. & Construction Innovation & 97 \\
\hline 12. & Feedback & 70 \\
\hline
\end{tabular}

Table 4. Buildability principle ranking based on frequency value.

\begin{tabular}{|c|l|}
\hline Factors/principle & \multicolumn{1}{|c|}{ Factors } \\
\hline 1 & Construction Knowledge \\
\hline 2 & Team Skill \\
\hline 3 & Construction Method \\
\hline 4 & Construction Innovation \\
\hline 5 & Available Resources \\
\hline 6 & Program \\
\hline 7 & Integration \\
\hline 8 & Specification \\
\hline 9 & Accessibility \\
\hline 10 & Program \\
\hline 11 & Feedback \\
\hline 12 & External Factor \\
\hline
\end{tabular}




\section{Conclusions}

The role of the contractor in enhancing buildability to achieve the project objectives is focused on twelve factors where the five most important factors are construction knowledge, team skill construction method, construction innovation, available resources. However, other principles cannot be ignored and are factors that must be considered by contractors in improving buildability. Those factors include program, integration, specification, accessibility, feedback and external factors.

\section{References}

1. Y.L.D. Adianto, D.N. Gunawan, Liana, Jurnal Teknik Sipil 7, 1 (2006)

2. H. Sulistio, Magawaty, Jurnal Media Komunikasi Teknik Sipil 19, 1 (2013)

3. CIRIA. Buildability: An assessment. Special Publication 26 (Construction Industry Research and Information Association, London, 1983)

4. CII. Constructability. A primer publication 3-1 (Construction Industry Institute, Austin, 1986)

5. Proctor and Gamble, Buildability-it work, building and technology bulletin (1976)

6. W.T.J. Adi, 2000. Peran konsultan perencana dalam peningkatan constructability (Tesis, ITS, Surabaya, 2000)

7. J.S. Russel, K.E. Swiggum, J.M. Shapiro, A.F. Alaydrus, 1994, J. of Performance of Constructed Facilities 8,1 (1994) 